\title{
Hypoglycemic and Antioxidant Effects of Subcoriacin in Normal and Streptozotocin-induced Diabetic Rats
}

\author{
José M. Narváez-Mastache, ${ }^{1}$ Claudia Soto ${ }^{2}$ and Guillermo Delgado ${ }^{1 *}$ \\ ${ }^{1}$ Instituto de Química de la Universidad Nacional Autónoma de México, Circuito Exterior, Ciudad Universitaria, Coyoacán \\ 04510, México, D. F. delgado@unam.mx. Telephone +52 55-5622-4446 \\ 2 Departamento de Sistemas Biológicos, Universidad Autónoma Metropolitana-Xochimilco. Calzada del Hueso 1100, Col. Villa \\ Quietud, México, DF CP 04960, México, D. F.
}

Received August 23, 2010; Accepted December 10, 2010

\begin{abstract}
Subcoriacin (1) is a 3-aryl-6-prenylcoumarin isolated from Eysenhardtia subcoriacea that has shown antioxidant activity in vitro, and has shown to scavenge free radicals and also to improve the reduced glutathione levels in pancreatic homogenates. The present investigation evaluates the protective effect of $\mathbf{1}$ against oxidative injury in normal and streptozotocin (STZ)-induced diabetic rats. The i.p. administration of 1 at a dose of $100 \mathrm{mg} / \mathrm{kg}$ body weight for $5 \mathrm{~d}$, significantly decreased blood glucose levels and improved the endogenous antioxidant system. Also, a significant increase in the activities of the antioxidant enzymes glutathione peroxidase (GSHPx), superoxide dismutase (SOD) and catalase (CAT) occurred. Combined treatment of rats with $1(100 \mathrm{mg} / \mathrm{kg})$ and STZ significantly reduced the pancreatic levels of thiobarbituric acid reactive substances (TBARS) levels. Likewise, significant increases in the activities of the antioxidant enzymes together with a decrease in blood glucose levels in both treatments were observed. The results demonstrate and support the relationship between the hypoglycemic and antioxidant activities displayed by the natural compound $\mathbf{1}$.

Keywords: Subcoriacin, 3-arylcoumarin, natural products, antioxidant system, diabetes mellitus, pancreas, superoxide dismutase, catalase, glutathione, glutathione peroxidase.
\end{abstract}

Diabetes mellitus is a complex metabolic disorder characterized by high blood glucose levels (hyperglycemia) due to the inability of the body's cells to utilize glucose properly. Cumulative evidence has shown that poorly and erratically controlled hyperglycemia produces abnormally high levels of reactive oxygen species (ROS) [1]. The high production of ROS initiates the depletion of the non-enzymatic and enzymatic antioxidant defenses [2]. When ROS formation overwhelms the capacity of the cellular antioxidant defenses, these reactive substances could react with essential molecules such as lipids, proteins and DNA, leading to histological changes as well as functional alterations [3]. In fact, it has been demonstrated that late diabetic complications arise from an exacerbated ROS formation and a depletion of the capacity of antioxidant system [4]. The increase of the ROS levels is related to the activation of multiple non-enzymatic, enzymatic and mitochondrial pathways by high blood glucose levels [5]. These include activation of protein kinase $\mathrm{C}$ isoforms, increased hexosamine pathway, glucose autooxidation, increased methylglyoxal and advanced glycation end-product (AGE) formation as well as the increased flux through the polyol pathway [6]. Additionally, metabolic stress is exacerbated by changes in energy metabolism and levels of inflammatory mediators [7].
Resumen. La subcoriacina (1) es una 3-aril-6-prenilcoumarina aislada de Eysenhardtia subcoriacea que ha mostrado actividad antioxidante, capacidad de atrapamiento de radicales libres y mejora de los niveles de glutatión reducido en homogenados de páncreas de rata. La presente investigación evalúa el efecto protector de $\mathbf{1}$ frente a daños oxidativos en ratas normales y en ratas diabetizadas con estreptozotocina (STZ). La administración i.p. de 1 en dosis de $100 \mathrm{mg} / \mathrm{kg}$ de peso por cinco días disminuyó significativamente los niveles de glucosa sanguínea y mejoró el sistema antioxidante endógeno. Se observó un aumento significativo en las actividades de las enzimas antioxidantes glutatión peroxidasa (GSHPx), superóxido dismutasa (SOD) y catalasa (CAT). El tratamiento combinado en ratas de $\mathbf{1}$ (100 $\mathrm{mg} / \mathrm{kg}$ ) y STZ disminuyó significativamente los niveles pancreáticos de substancias reactivas al ácido tiobarbitúrico (SRATB). Asímismo, se observaron en ambos tratamientos aumentos significativos en las actividades de enzimas antioxidantes junto con el decremento de los niveles de azúcar sanguíneo. Los resultados demuestran y apoyan la relación entre las actividades hipoglicémicas y antioxidantes mostradas por el compuesto natural 1.

Palabras clave: Subcoriacina, 3-arilcoumarina, productos naturales, sistema antioxidante, diabetes mellitus, páncreas, superóxido dismutasa, catalasa, glutatión, glutatión peroxidasa.

In this context, recent attention has been focused on the analysis of the protective antioxidant biochemical function of several plants [8] as well as some natural products [9-12] which displayed not only radical scavenger capacity, but also improved the antioxidant enzymatic system. Indeed, the protective effects of terpenes, flavonoids and polyphenols on several models of diabetes mellitus have been demonstrated. For example, silymarin [9], 3-O-acetyl-11 $\alpha, 12 \alpha$-epoxy-oleanan-28,13ß-olide [10], and umbelliferone [11] have been shown to confer protective effects and to improve the antioxidant enzymatic system in streptozotocin-induced diabetic rats.

Subcoriacin (1), a 3-arylcoumarin isolated from the bark and branches of Eysenhardtia subcoriacea [13], possesses structural characteristics that allow ready oxidation and radical scavenging effects (delocalized $\pi$-electrons and two aromatic groups). Subcoriacin protected against the damage in rat- pancreatic homogenate, scavenging the radicals formed by the AAPH and also elevating the pancreatic reduced glutathione levels [13]. Therefore, this work focused an assessment of the protective effect of subcoriacin (1) against STZ-induced damage in normal rats. Streptozotocin is an antibiotic and anticancer agent widely used for inducing type I and II diabetes in a variety of animals. The diabetogenic effect has been related 
to the formation of high levels of ROS that occurred during the degradation of STZ in the blood [14]. We have shown earlier that STZ produced oxidative stress and depletion of antioxidant systems in the rat pancreas $[10,11]$. As a continuation of our search for secondary metabolites with hypoglycemic and antioxidant activities $[10,12]$, the present report examines the hypoglycemic activity as well as the protective effectiveness of $\mathbf{1}$ in the pancreas from both normal and STZ-treated rats.<smiles>O=c1oc2cc(O)c(CC=C(CO)CO)cc2cc1-c1cc2c(cc1O)OCO2</smiles>

\section{Results and Discussion}

The administration of $\mathbf{1}$ to normal rats for $5 \mathrm{~d}$ significantly decreased the serum glucose concentration $(4.77 \pm 0.56 \mathrm{mM})$ respect to the untreated group $(6.42 \pm 0.27 \mathrm{mM})$. STZ treatment produced a significant increase $(18.62 \pm 0.20 \mathrm{mM})$ in serum glucose with respect to the untreated group. Combined treatment of $\mathbf{1}$ and the diabetogenic drug significantly reduced $(8.08 \pm 0.48 \mathrm{mM})$ the elevated serum glucose levels induced by STZ after a period of $5 \mathrm{~d}$ (Fig. 1). Compound 1 alone did not induce any change in pancreatic TBARS levels (Fig. 2). STZ treatment significantly increased the TBARS levels. Immediately after diabetes mellitus induction with STZ, treatment with 1 for $5 \mathrm{~d}$ reduced the formation of pancreatic TBARS to levels approaching those seen in the untreated control.

STZ treatment significantly increased SOD and GSHPx activities but decreased CAT activity (Figs. 3-5) as compared to the activities seen in the untreated control. The administration of 1 alone to normal rats for $5 \mathrm{~d}$ increased the pancreatic activity of SOD enzyme, in comparison to the untreated group,

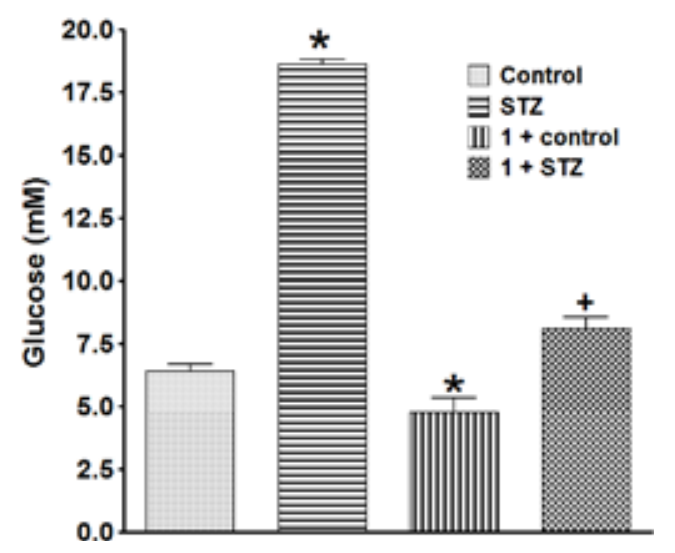

Fig. 1. Effect of subcoriacin (1) on blood glucose concentration. Each bar represents the mean + S.E.M. of $\mathrm{n}=6$ animals. ${ }^{*} p<0.05$, when compared to control group, ${ }^{+} p<0.05$ when compared to STZ treated group, respectively. Control: Group 1, untreated rats. STZ: Group 2, diabetic rats. 1+control: Group 3, normal treated rats with 1. 1+STZ: Group 4, diabetic treated rats with 1.

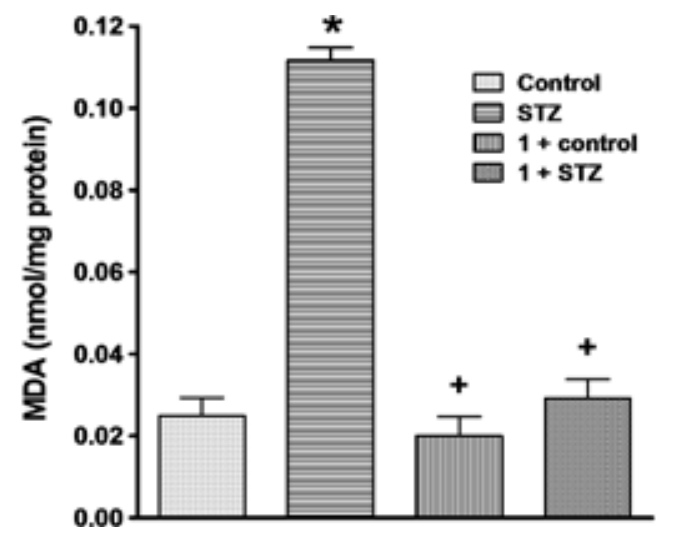

Fig. 2. Effect of subcoriacin (1) on pancreatic malondialdehyde levels (measured as TBARS). Each bar represents the mean + S.E.M. of $\mathrm{n}=6 .{ }^{*} p<0.05$ when compared to control group and ${ }^{+} p<0.05$ when compared to STZ treated group, respectively. Control: Group 1, untreated rats. STZ: Group 2, diabetic rats. 1+control: Group 3, normal treated rats with 1. 1+STZ: Group 4, diabetic treated rats with 1.

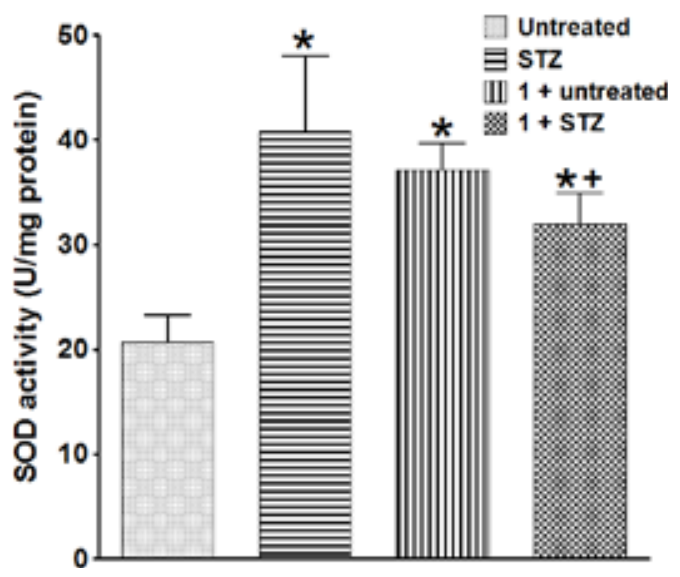

Fig. 3. Effect of subcoriacin (1) on the superoxide dismutase (SOD) pancreatic activity $\left(\mathrm{U} \mathrm{mg}\right.$ protein $\left.{ }^{-1}\right)$. Each bar represents the mean + S.E.M. of $\mathrm{n}=6 .{ }^{*} p<0.05$ when compared to control group and ${ }^{+} p$ $<0.05$ when compared to STZ treated group, respectively. Control: Group 1, untreated rats. STZ: Group 2, diabetic rats. 1+control: Group 3, normal treated rats with 1. 1+STZ: Group 4, diabetic treated rats with 1 .

as well as the GSHPx and CAT activities were significantly increased $(p<0.05)$. Combination therapy with STZ and Subcoriacin (1) for $5 \mathrm{~d}$ decreased the pancreatic SOD activity with respect to diabetic rats treated with STZ alone $(p<0.05)$. In contrast, dual treatment with STZ and Subcoriacin increased the GSHPx and CAT activities compared to treatment with STZ alone (Figs. 4 and 5).

Reactive oxygen species and other reactive radical have been defined as important causative factors for the development of diabetic complications [4]. This observation has led to considerable interest in the search for secondary metabolites that protect the organism against ROS and boost defense systems. Thus, natural antioxidants have been assayed in several diabetic models. We have previously demonstrated that some terpenes and flavonoids isolated from some Eysenhardtia 


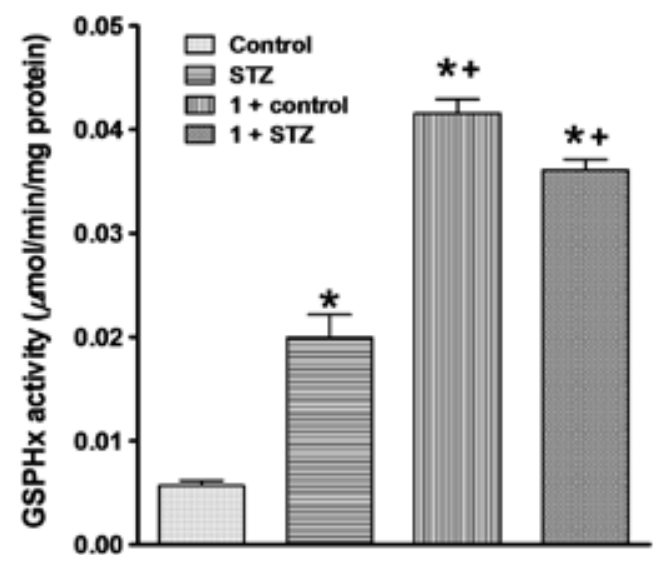

Fig. 4. Effect of subcoriacin (1) on the glutathione peroxidase (GSHPx) pancreatic activity $\left(\mu \mathrm{M}\right.$ NADPH/NADP $+\min ^{-1}$. per $\mathrm{mg}$ protein). Each bar represents the mean + S.E.M. of $\mathrm{n}=6 .{ }^{*} p<0.05$ when compared to control group and ${ }^{+} p<0.05$ when compared to STZ treated group, respectively. Control: Group 1, untreated rats. STZ: Group 2, diabetic rats. 1+control: Group 3, normal treated rats with 1. 1+STZ: Group 4, diabetic treated rats with 1.

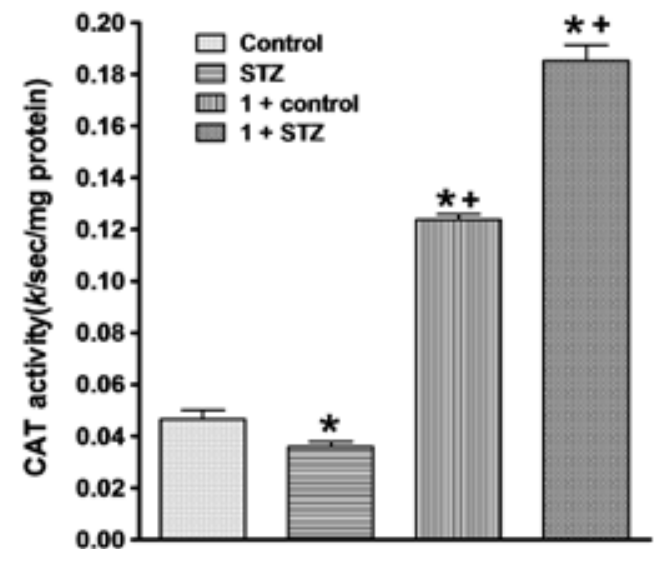

Fig. 5. Effect of subcoriacin (1) on the catalase (CAT) pancreatic activity $\left(k \cdot s^{-1} \cdot \mathrm{mg}\right.$ of protein $\left.{ }^{-1}\right)$. Each bar represents the mean + S.E.M. of $\mathrm{n}=6 .{ }^{*} p<0.05$ when compared to control group and ${ }^{+} p$ $<0.05$ when compared to STZ treated group, respectively. Control: Group 1, untreated rats. STZ: Group 2, diabetic rats. 1+control: Group 3, normal treated rats with 1. 1+STZ: Group 4, diabetic treated rats with 1.

species decreased oxidative stress and enhanced the activities of several components of the endogenous antioxidant system in vitro; specifically, GSH levels increased significatively [10]. Also, a triterpene lactone isolated from the bark of Eysenhardtia platycarpa has shown protective effects against the cellular injury induced by STZ [10], improving the endogenous antioxidant system. Therefore, the main finding in this study was that $\mathbf{1}$ protected against STZ-induced damage and increased the pancreatic activities of antioxidant enzymes. Similarly, Ramesh et al. [11]. demonstrated that the treatment of normal and diabetic rats with the coumarin umbelliferone $(30 \mathrm{mg} / \mathrm{kg}$ ) for $45 \mathrm{~d}$, decreased the plasma glucose levels, and also restored lipid peroxidation markers, both nonenzymatic and enzymatic antioxidants, in the liver.
In this study we observed that the i.p. administration of STZ to male rats increased food consumption and decreased body weight by $5 \mathrm{~d}$ after induction of diabetes. These symptoms may be due to accelerated degradation of tissue proteins as the animal enters negative nitrogen balance. Also, STZ treatment produced an increase in serum glucose concentration as it was showed by some authors $[15,16]$ and an increase in pancreatic TBARS, suggesting that lipid peroxidation occurs well after induction of hyperglycemia. These results are in accordance with the studies of Soto et al. [9, 17], whom used the same treatment schedule for pancreatic damage. In accordance, Nagasao et al. [18], showed severe morphological damage in the rat endocrine pancreas within $12 \mathrm{~h}$ after STZ administration. These results indicate that the diabetogenic effect of STZ is related to the increase of the production of $\mathrm{H}_{2} \mathrm{O}_{2}$ and $\mathrm{HO}^{\circ}$ in blood and pancreatic $\beta$-cells [10]. Therefore, the cells undergo destruction by necrosis and the production of insulin is decreased.

Combined treatment with $1(100 \mathrm{mg} / \mathrm{kg})$ and STZ for 5 d significantly reduced the elevated serum glucose concentration (Fig. 1) and TBARS levels (Fig. 2) induced by STZ. This effect suggested that $\mathbf{1}$ principally induces a decrease of the radicals formed during the diabetic induction. The effects of 1 on serum glucose and pancreatic lipid peroxidation in STZ-induced rats may be correlated with the rise in pancreatic GSH induced by $\mathbf{1}$ in the in vitro model observed previously [13]. Therefore, 1 may improve both the antioxidant system and serum glucose regulation, which is consistent with the observed antidiabetic effect. Paolisso et al. have proposed that the ratio of GSH/GSSG plays a critical role in the glucose homeostasis of diabetes mellitus. Thiol groups may be important in the intracellular and membrane redox states of pancreatic $\beta$-cells and thus influence their secretory function [19].

In addition, we found that the administration of STZ to normal rats increased the activity of SOD and GSHPx, but decreased the activity of CAT in the pancreas after $5 \mathrm{~d}$ of treatment. The antioxidant enzymatic complex represents the most important endogenous system for the elimination of the reactive substances formed in the organism. SOD protects tissues from superoxide anion radical $\left(\mathrm{O}_{2}{ }^{--}\right)$, while GSHPx and CAT are responsible for the detoxification of significant amounts of $\mathrm{H}_{2} \mathrm{O}_{2}$. Increased activities of antioxidant enzymes have been demonstrated in some organs of diabetic rats, possibly as a defense mechanism against the production of ROS as a consequence of hyperglycemic states [20]. This may be related with an increase of antioxidant gene expression [21]. In addition, some studies shown decreased SOD, GSHPx, and CAT activities after $14 \mathrm{~d}$ of STZ treatment in rats, suggesting impaired antioxidant under conditions of exacerbated ROS formation [17]. The decrease of the CAT activity (Fig. 5) in the group treated with STZ alone could be due to the high levels of $\mathrm{O}_{2}{ }^{--}$ formed during the degradation of the diabetogenic drug. It has been proposed that the activity displayed by CAT could be inhibited by high levels of $\mathrm{O}_{2}{ }^{--}$but not by that of GSHPx [22]. On its own, 1 increases the activity of the endogenous antioxidant enzymatic system, suggesting that the antioxidant proper- 
ties displayed by 1 [13] also contribute to the neutralization of the radicals formed and, therefore, hyperglycemia does not develop. This may be related with the findings of Ullman et al. [23], whom demonstrated the ability of natural compounds, as quercetin and genistein (structurally related with $\mathbf{1}$ ), to activate SOD and GSH gene promoter activities. In this way, Rhördanz [24] showed that daidzein (a flavonoid) can directly activate the rat catalase promoter region. These evidences may contribute to explain our results of the antioxidant enzymes activities. In addition, Hatano et. al. found that ethanolic extracts of some Glycyrrhiza species, containing principally prenylchalcones and 6-prenylcoumarins, showed inhibitory effects on monoamine oxidase (MAO) and xanthine oxidase (XAO) activities [24-26], which are implicated in $\mathrm{O}_{2}{ }^{-}$formation. The inhibition of these enzymes will allow expression of the activity of the pancreatic antioxidant system, which was observed in the combined treatment group. Previously, similar variations have been observed in other phenolic compounds such as catechin and genistein [23]. Also, it has been shown that the 3-aryl-6-prenylcoumarins glycycoumarin, glycyrin, dehydroglyasperin C and D, isolated of Glycyrrhiza uralensis, also are ligands of the peroxisome proliferator-activated receptor (PPAR- $\gamma$ ). The PPAR- $\gamma$ antagonists improve body fat distribution and glucose absorption [27]. The structure of $\mathbf{1}$ is related to the compounds isolated from the Glycyrrhiza species, therefore, the hypoglycemic effect displayed by $\mathbf{1}$ could be related to the activation of these receptors. The protection against lipid peroxidation offered by the antioxidant system and the effect of $\mathbf{1}$ on this system appears to be relevant responses to ROS-induced membrane damage.

In summary, all these evidences and the results obtained suggest the protective effect of $\mathbf{1}$ against the pancreatic damage produced by free radicals in the induction of diabetes mellitus by STZ in rats.

\section{Experimental}

Chemicals. Subcoriacin (1) was isolated from the bark and branches of Eysenhardtia subcoriacea (Fabaceae) following the procedures previously described [13]. Streptozotocin, sodium dihydrogen phosphate monohydrate, anhydrous sodium hydrogen phosphate, ethylenediaminetetraacetic acid (EDTA), reduced glutathione (GSH), xanthine, disodium salt of bathocuproine-disulphonic acid (BDA), diethylenetriamine pentaacetic acid (DETAPAC), bovine serum albumin, nitrotetrazolium blue (NTB), NADPH, xanthine oxidase (Xoxd), glutathione reductase (GSHRd) and $\mathrm{H}_{2} \mathrm{O}_{2}$ were purchased from Sigma-Aldrich Co. (St. Louis, MO, USA). All other chemicals were used reagent grade and were purchased with commercial dealmakers. Double distilled water was used for all biochemical assays. Apparatus. Compound 1 was purified by chromatography on a Merck Kiesel gel $60(0.040-0.863 \mathrm{~mm})$ column and identified by comparison with authentic samples from our laboratory using thin-layer chromatography (TLC) and comparison of the spectroscopic data. Animals. Male Wistar rats
(180-220 g b. wt.) were obtained from Instituto de Fisiología Celular, Universidad Nacional Autónoma de México (IFC, UNAM). The rats were randomly grouped in six rats each, housed in polyacrylic cages and maintained at standard laboratory conditions of room temperature and humidity $\left(25 \pm 2{ }^{\circ} \mathrm{C}\right.$ and $60 \%$, respectively) with a $12 \mathrm{~h} / 12 \mathrm{~h}$ dark and light cycle. They were allowed free access to a standard dry pellet diet (Harlan Teklad Rat Chow), water ad libitum and allowed to acclimatize for $2 \mathrm{~d}$. The experiments reported in this study were carried out following the guidelines stated to laboratory animal care (NIH publication \#85-23, revised 1985 and NOM062-ZOO-1999).

Experimental Design. After of the adaptation period, the rats were subjected to a $6 \mathrm{~h}$ fast and divided on four experimental groups of 6 rats each. Each group was treated according the following protocol: group 1: untreated rats, received via oral 1 $\mathrm{ml}$ of carboxymethyl cellulose (CMC, $5 \%$ in water) daily for $5 \mathrm{~d}$; group 2: diabetic rats, treated with a single intraperitoneal injection of STZ $(65 \mathrm{mg} / \mathrm{kg} \mathrm{b}$. wt.) freshly dissolved in citrate buffer $(0.01 \mathrm{M}, \mathrm{pH} 4.7)$. The injection volume was prepared to contain $1.0 \mathrm{~mL} / \mathrm{kg}$. After $5 \mathrm{~d}$, blood glucose concentration was determined by enzymatic glucose oxidase method using a commercial glucometer, and the animals with a concentration higher than $225 \mathrm{mg} / \mathrm{dL}$ were used for biochemical analysis; group 3: normal treated rats, treated with $1(100 \mathrm{mg} / \mathrm{kg} \mathrm{b}$. wt., oral) for 5 days. Subcoriacin was suspended in CMC at 25 $\mathrm{mg} / \mathrm{mL}$; and group 4: diabetic treated rats, each rat received one administration of STZ, immediately one doses of $\mathbf{1}$ (100 $\mathrm{mg} / \mathrm{kg} \mathrm{b}$. wt.) and after 4 dose ( $24 \mathrm{~h}$ each) were administrated. At the end of the treatment, animals were subjected to a $5 \mathrm{~h}$ fast previous the biochemical analysis. Rats were anesthetized with sodium pentobarbital $(25.2 \mathrm{mg} / \mathrm{kg}$, b. wt.; i. p.). Blood glucose was drawn by cardiac puncture $(3 \mathrm{~mL})$. Pancreas were removed, cleaned of gross adventitial tissue and immediately frozen on ice. The tissue of each rat was homogenized $(10 \%$ $\mathrm{w} / \mathrm{v}$ ) in ice cold Phosphate Buffer Solution (PBS, $50 \mathrm{mmol} / \mathrm{L}$, $\mathrm{pH}$ 7.4) for $30 \mathrm{~s}$ using a Polytron homogenizer. The homogenate was filtered through cheese cloth and the filtrate was centrifuged at $3000 \mathrm{rpm}$ for $5 \mathrm{~min}$ using refrigerated centrifuge (Beckman Model J2-21). The resultant supernatant was used for measurement of thiobarbituric reactive species (TBARS) levels, expressed as nmol of malondialdehyde (MDA) per $\mathrm{mg}$ of protein. The activities of superoxide dismutase (SOD), glutathione peroxidase (GSHPx) and catalase (CAT) were also assayed. Protein concentration was determined in $100 \mu \mathrm{L}$ of the homogenate using the Bradford procedure [28].

Determination of TBARS. TBARS in the tissue was estimated by the method of Ohkawa et al. [29]. To $200 \mu \mathrm{L}$ of tissue homogenate $(10 \mathrm{mg} / \mathrm{mL}), 50 \mu \mathrm{L}$ of BHT $(2 \%$ in EtOH and $700 \mu \mathrm{L}$ of a mixture of thiobarbituric acid (TBA) reagent and trichloroacetic acid (TCA, 5\%) were added. The content was well mixed and boiled for $1 \mathrm{~h}$ at $95{ }^{\circ} \mathrm{C}$. After this time, the tubes were then ice-cooled and absorption measured at $532 \mathrm{~nm}$. 
Assay of SOD The activity of SOD in tissue was assayed using the method of Kakkar et al. [30].To $500 \mu \mathrm{L}$ of supernatant (approx. 2.5 to $5 \mathrm{mg}$ protein ${ }^{-1}$ ), $800 \mu \mathrm{L}$ of $\mathrm{CHCl}_{3}: \mathrm{EtOH}$ (3:5) was added. The mixture was mixed in vortex and centrifuged at $3000 \mathrm{rpm}$ for $30 \mathrm{~min}$ at $4{ }^{\circ} \mathrm{C}$. To $500 \mu \mathrm{L}$ of supernatant, 2.45 $\mathrm{mL}$ of reagent mixture for SOD [contained xanthine $(98 \mu \mathrm{L}$, $0.3 \mathrm{mmol} / \mathrm{L}$ in $\mathrm{NaOH} 0.05 \mathrm{~N})$, DETAPAC $(98 \mu \mathrm{L}, 1 \mathrm{mmol} / \mathrm{L})$, bovine serum albumin $(490 \mu \mathrm{L}, 0.25 \mathrm{mg} / \mathrm{ml})$, NTB $(98 \mu \mathrm{L}$, $25 \mathrm{mmol} / \mathrm{L}), \mathrm{BDA}(98 \mu \mathrm{L}, 250 \mathrm{mmol} / \mathrm{L}), \mathrm{Na}_{2} \mathrm{CO}_{3}(98 \mu \mathrm{L}, 40$ $\mathrm{mmol} / \mathrm{L}, \mathrm{pH} 10.2)$ and water $1.47 \mathrm{~mL}$ ] was added. Xoxd (50 $\mu \mathrm{L}, 20 \mathrm{U} / \mathrm{mL}$ in glycerol) was added to start the reaction and incubated at $25^{\circ} \mathrm{C}$ for $20 \mathrm{~min}$. After the incubation the reaction was concluded by the addition of $\mathrm{CuCl}_{2}(1 \mathrm{~mL}, 0.8 \mathrm{mmol} / \mathrm{L})$. The absorbance was measured at $560 \mathrm{~nm}$ against to reagent mixture for SOD.

Assay of GSHPx. GSHPx was assayed according to the method of Paglia and Valentine [31], described by Kakkar et al. [30]. To a mixture of PBS (200 $\mu \mathrm{L}, 75 \mathrm{mmol} / \mathrm{L}, \mathrm{pH} 7)$, GSH $(50 \mu \mathrm{L}, 60 \mathrm{mmol} / \mathrm{L})$, GSHRd $(100 \mu \mathrm{L}, 30 \mathrm{U} / \mathrm{mL})$, EDTA $(100$ $\mu \mathrm{L}, 15 \mathrm{mmol} / \mathrm{L})$ and NADPH $(100 \mu \mathrm{L}, 3 \mathrm{mmol} / \mathrm{L})$ were added $250 \mu \mathrm{L}$ of supernatant and $250 \mu \mathrm{L}$ of water. The reaction was started by addition of $\mathrm{H}_{2} \mathrm{O}_{2}(100 \mu \mathrm{L}, 7.5 \mathrm{mmol} / \mathrm{L})$. The rate of change of absorbance during the conversion of NADPH to $\mathrm{NADP}^{+}$was recorded spectrophotometrically at $340 \mathrm{~nm}$ for 4 min. GSHPx activity was expressed as $\mu$ mol of NADPH oxidized to NADP ${ }^{+} \mathrm{min}^{-1} \mathrm{mg}$ protein ${ }^{-1}$ using an extinction coefficient $\left(6.22 \mathrm{mM}^{-1} \mathrm{~cm}^{-1}\right)$ for NADPH [31].

Assay of CAT. The activity was estimated following the method of Aebi [32] and described by Kakkar et al. [30]. PBS $1.9 \mathrm{~mL}$ and $50 \mu \mathrm{L}$ of supernatant was added and mixed into a cuvette. The reaction was started by the addition of freshly prepared $\mathrm{H}_{2} \mathrm{O}_{2}(1.0 \mathrm{~mL}, 30 \mathrm{mmol} / \mathrm{L})$. The rate of decomposition of $\mathrm{H}_{2} \mathrm{O}_{2}$ was measured spectrophotometrically at $240 \mathrm{~nm}$. The enzyme activity for $\mathrm{H}_{2} \mathrm{O}_{2}$ was expressed as $k \mathrm{~s}^{-1} \mathrm{mg}$ protein $^{-1}$, where $k$ is the first-order rate constant.

Other Methods. Glucose blood levels were measured in 50 $\mu \mathrm{L}$ of serum using the method of Baner [33]. All samples were measured in duplicates.

Statistical Analysis. Data is expressed as means \pm S.E.M. of 6 rats of each group. The biochemical parameters were analyzed statistically using one-way analysis of variance (ANOVA) followed by the Tukey's Multiple Comparison Test using the "Graph Pad Prism 5" statistic computer program. The minimum level of significance was considered at $p<0.05$ and $p<$ 0.01 in each case.

\section{Acknowledgments}

This work was supported by Universidad Nacional Autónoma de México, by Universidad Autónoma Metropolitana Campus Xochimilco, and by CONACYT. The authors thank María Isabel Chávez, Beatriz Quiroz, Ma. Teresa Ramírez-Apan, and
Antonio Nieto (Instituto de Química de la UNAM) for technical assistance. We also thank Ramiro Cruz Durán (Herbario de la Facultad de Ciencias, UNAM) for collection and identification of the plant material.

\section{References}

1. West, I. C., Diabet. Med. 2000, 17, 171-180.

2. Martín-Galán, P.; Carrascosa, A.; Gussinyé, M.; Domínguez, C. Free Rad. Biol. Med. 2003, 34, 1563-1574.

3. Toren, F. Curr. Opin. Cell Biol. 2003, 15, 247-254.

4. Balderas, F. L.; Méndez, J. D. J. Mex. Chem. Soc. 1998, 42, 189-195.

5. Baynes, J. W. Diabetes 1991, 40, 405-412.

6. Brownlee, M. Nature 2001, 414, 813-820.

7. Mehta, J. L.; Rasouli, N.; Sinha, A K.; Molavi, B. Inter. J. Biochem. Cell Biol. 2006, 38, 794-803.

8. Sabu, M. C.; Kuttan, R. J. Ethnopharmacol. 2002, 81, 155-160.

9. Soto C.; Recoba, R.; Barrón, H.; Alvarez, C.; Favari, L. Comp. Biochem. Physiol. Part C, 2003, 136, 205-212.

10. Narváez-Mastache, J. M.; Soto, C.; Delgado, G. Biol. Pharm. Bull. 2007, 30, 1503-1510.

11. Ramesh, B.; Pugalendi, K. V. Life Sci. 2006, 79, 306-310.

12. León, A.; Reyes, B. M.; Chávez, M. I.; Toscano, R. A.; Delgado, G. J. Mex. Chem. Soc. 2009, 53, 193-200.

13. Narváez-Mastache, J. M.; Novillo, F.; Delgado, G. Phytochemistry 2008, 69, 451-456.

14. Szkudelski, T. Physiol. Res. 2001, 50, 536-546.

15. Adewole, A.; Caxton-Martins, E.; Ojewole, J. Afr. J. Trad. CAM 2007, 4, 64-74.

16. Zhang, S.; Chai, F.; Yan, H.; Guo, Y.; Harding, J. Molec. Vision 2008, 14, 862-870.

17. Soto, C.; Pérez, B.; Favari, L.; Reyes, J. Comp. Biochem. Physiol. 1998, 119C, 125-129.

18. Nagasao, J.; Yoshioka, N.; Amasaki, H.; Tsuijio, M.; Ogawa, M.; Taniguchi, K.; Mutoh, K. Anat. Histol. Embryol. 2005, 34, 42-47.

19. Paolisso, G.; Di Maro, G.; Pizza, G.; D’Amore, A.; Sgambato, S.; Tesauro, P.; Varricchio, M.; D'Onofrio, F. Am. J. Physiol. 1992, 263, E435-E440.

20. Kakkar, R.; Kalra, J.; Mantha, S.; Prasad, K. Mol. Cell. Biochem. 1995, 151, 113-119.

21. Franco, A.; Odom, R.; Rando, T. Free Radic. Biol. Med. 1999, 27, 1122-1132.

22. Shimizu, N.; Kobayashi, K.; Hayashi, K. J. Biol. Chem. 1984, 259, 4414-4418.

23. Ullman, K.; Wiencierz, A. M.; Müller, C.; Thierbach, R.; Steege, A.; Toyokuni, S.; Steinberg, P. Free Rad. Res. 2008, 42, 746-753.

24. Röhrdanz, E; Ohler, S.; Tran-Thi, Q.; Kahl, R. J. Nutr. 2002, 132, $370-375$.

25. Kono, Y.; Fridovich, I. J. Biol. Chem. 1983, 258, 13646-13648.

26. Hatano, T.; Fukuda, T.; Liu, Y. Z.; Noro, T.; Okuda, T. Yakugaku Zasshi 1991, 111, 311-321.

27. Mae, T.; Kishida, H.; Nishiyama, T.; Tsukagawa, M.; Konishi, E.; Kuroda, M.; Mimaki, Y.; Sashida, Y.; Takahashi, K.; Kawada, T.; Nakagawa, K.; Kitahara, M. J. Nutr. 2003, 133, 3369-3377.

28. Bradford, M. Anal. Biochem. 1976, 72, 248-254.

29. Ohkawa, H.; Ohishi, N.; Yagi, K. Anal. Biochem. 1979, 95, 351-358.

30. Kakkar, R.; Mantha, S. V.; Radhi, J.; Prasad, K. Clin. Sci. 1998, 94, 623-632.

31. Paglia, D. E.; Valentine, W. N. J. Lab. Clin. Med. 1967, 70, 158169.

32. Aebi, H., Catalase: In "Methods of Enzymatic Analysis", Bergmeyer HV, Chemie, Weinheim, F.R.G., 1974, 673-684.

33. Baner, C., Chemical Laboratory Methods, Academic Press, New York, 1985. 